\title{
Late preterm infants' growth and body composition after discharge
}

\author{
Paola Roggero ${ }^{*}$, Maria Lorella Giannì, Nadia Liotto, Pasqua Piemontese, Fabio Mosca \\ From XX National Congress of the Italian Society of Neonatology \\ Rome, Italy. 9-11 October 2014
}

\section{Background}

The proportion of late preterm births has markedly increased during the past two decades, accounting for $70 \%$ of preterm births [1]. There is evidence that monitoring not only the quantity but also the quality of growth, in terms of body composition changes, may play an important role in gaining further insight into the relationship between birth weight and time in utero on early growth pattern and future health [2]. To our knowledge, data regarding the early dynamic features of growth and body composition changes of late preterm infants are scarce [3-5]. The aim of this study was to compare growth and body composition of late preterm infants to that of very preterm and full term infants.

\section{Materials and methods}

Observational longitudinal study. Forty-nine late preterm infants and 63 adequate for gestational age very preterm infants were included in the study. Forty healthy, fullterm, breast-fed infants were enrolled as a reference group. Anthropometric parameters and body composition by an air displacement plethysmography system were assessed at term, at 1 and 3 months of corrected age in all groups.

\section{Results}

Basal characteristics of the study population are shown in table 1.

Table 1 Basal characteristics and anthropometric and body composition parameters at term and at 3 months of corrected age of the study population

\begin{tabular}{llll}
\hline & Full term infants & Late preterm infants & Very preterm infants \\
\hline Gestational age (wks) & $38.8 \pm 1.4$ & $35.3 \pm 0.75$ & $29.1 \pm 2.1$ \\
Birth Weight (g) & $3074 \pm 409$ & $2496 \pm 330$ & $1202 \pm 238$ \\
Birth length (cm) & $49.3 \pm 2$ & $44.8 \pm 1.7$ & $37.2 \pm 3.5$ \\
Birth head circumference (cm) & $34.2 \pm 1.17$ & $31.6 \pm 1.2$ & $29.07 \pm 2.1$ \\
Weight $\mathbf{4 0}$ wks (g) & $3074 \pm 409$ & $3396^{* \circ} \pm 390$ & $3015 \pm 403$ \\
Fat free mass $\mathbf{4 0}$ wks (g) & $2794 \pm 358$ & $2837^{\circ} \pm 255$ & $2459 \pm 320$ \\
Fat mass $\mathbf{4 0}$ wks (g) & $280 \pm 106$ & $559 \# \pm 196$ & $565 \pm 168$ \\
Weight $\mathbf{3}$ mo (g) & $5978 \pm 722$ & $6197^{\circ} \pm 589$ & $5557 \pm 669$ \\
Fat free mass $\mathbf{3}$ mo (g) & $4345 \pm 484$ & $4500 \wedge \pm 390$ & $4157 \pm 461$ \\
Fat mass $\mathbf{3}$ mo (g) & $1632 \pm 355$ & $1672 \wedge \pm 348$ & $1405 \pm 362$ \\
\hline
\end{tabular}

*late preterm vs full term $p=0.001$

- late preterm vs very preterm $p<0.001$

\# late preterm vs full term $p<0.001$

$\wedge$ late preterm vs very preterm $p=0.005$ 
Late preterm infants showed higher weight at term than full term and very preterm infants (table 1 ). Length (49.5 vs $47.5 \mathrm{~cm} ; \mathrm{p}<0.0001)$ and head circumference (35.2 vs $34.4 \mathrm{~cm} ; \mathrm{p}=0.004$ ) values were also bigger in late preterm infants at term than in very preterm infants. At 3 months of corrected age no significant difference in anthropometric parameters was found between late preterm and full term infants, whereas weight of late preterm infants was higher than that of very preterm infants.

With regard to body composition, fat mass at term of late preterm infants was similar to that of very preterm but significantly higher than that of full term. Fat free mass at term was not different between late preterm and full term infants while very preterm infants showed the lowest value.

At 3 months of corrected age, late preterm infants reached a similar body composition to full term infants, whereas very preterm infants still had the lowest values of weight, fat free mass and fat mass (table 1).

\section{Conclusions}

The present findings demonstrate that late preterm infants have an altered body composition at term corrected age in terms of high adiposity. Potential metabolic implications of these results need to be investigated.

Published: 9 October 2014

\section{References}

1. Dong Y, Yu JL: An overview of morbidity, mortality and long-term outcome of late preterm birth. World J Pediatr 2011, 7:199-204.

2. Dulloo AG, Jacquet J, Seydoux J, Montani JP: The thrifty "catch-up fat" phenotype: its impact on insulin sensitivity during growth trajectories to obesity and metabolic syndrome. Int J Obes (Lond) 2006, 30(Suppl 4): s23-35.

3. Santos IS, Matijasevich A, Domingues MR, Barros AJ, Victora CG, Barros FC: Late preterm birth is a risk factor for growth faltering in early childhood: a cohort study. BMC Pediatr 2009, 9:71.

4. Olhager $E$, Törnqvist $C$ : Body composition in late preterm infants in the first 10 days of life and at full term. Acta Paediatr 2014, 103:737-743.

5. Gianni ML, Roggero P, Liotto N, Amato O, Piemontese P, Morniroli D, Bracco B, Mosca F: Postnatal catch-up after late preterm birth. Pediatric Res 2012, 72:637-640.

doi:10.1186/1824-7288-40-S2-A27

Cite this article as: Roggero et al:: Late preterm infants' growth and body composition after discharge. Italian Journal of Pediatrics 201440 (Suppl 2):A27.

\section{Submit your next manuscript to BioMed Central} and take full advantage of:

- Convenient online submission

- Thorough peer review

- No space constraints or color figure charges

- Immediate publication on acceptance

- Inclusion in PubMed, CAS, Scopus and Google Scholar

- Research which is freely available for redistribution

Submit your manuscript at www.biomedcentral.com/submit
C Biomed Central 